\title{
Introductory editorial: advances in karst hydrogeology
}

\author{
Bartolomé Andreo
}

Published online: 7 March 2012

(c) Springer-Verlag 2012

Karst aquifers constitute $12 \%$ of the global land surface and store water on which approximately 20-25\% of the world's population depends, as it is stated in classical text books on karst. One-third of the surface area of Europe contains this type of aquifer, which supplies water to cities like London, Bristol, Paris, Montpellier, Vienna and Rome, to name just a few significant examples. In some countries, such as Slovenia and Austria, karst water contributes more than half of the drinking water supply and in many regions it is the only available source of fresh water. Moreover, karst aquifers are mostly upstream systems, acting as a water tower of fragile ecosystems that may be coastal and/ or correspond to urban areas subject to development. Karst areas also support unique ecosystems that are very rich in biodiversity, but their functioning, development and level of fragility remain largely unknown. Several karst systems are included in the UNESCO World Heritage list, and are characterised as strategic resources at local, national and international levels. The potential of karst areas in terms of hydro-geo-biodiversity, for instance, is widely recognised. These considerations illustrate the importance of the water stored in this type of medium and, therefore, the need for research into karst hydrogeology.

Unlike porous or fissured formations, karst systems have a particular heterogeneous structure and behaviour, characterised by the concentration of groundwater flow through a network of karst conduits, enclosed within a less permeable matrix and connected to a local discharge area, the karst spring. This combination of areas of high hydraulic conductivity/low storage capacity (karst conduits) and

B. Andreo $(\bowtie)$

Department of Geology and Centre of Hydrogeology,

University of Málaga, 28091 Málaga, Spain

e-mail: andreo@uma.es medium to low hydraulic conductivity/medium to high storage capacity (fractures and matrix systems) means that contaminants may readily penetrate the subsurface, reaching groundwater and then being rapidly transported over large distances.

Various research techniques have been developed, mainly based on the analysis of the natural response of karst aquifers, and include spring discharge (hydrographs), chemical composition (chemographs) and temperature and isotopes (both stable and radioactive). There has also been progress in the implementation of techniques such as dye tracers, with tracers (especially fluorescent ones) that are environmentally innocuous and provide a higher sensitivity. Recent experiments have been done with methods based on natural tracers, such as total organic carbon, natural fluorescence, turbidity and bacteria from the soil. The combined use of several of these methods allows the comparison of the results of various research programs and the ability to reach well-grounded conclusions.

The specificity of the karst medium is fully accepted at all levels of hydrogeological knowledge, as shown by the fact that most of the international associations concerned with water, geological and environmental sciences have specific karst committees. One case is the Karst Commission of the International Association of Hydrogeologists (http://www.iah.org/karst), which organises many activities (conferences, meetings, training courses, publications, handbooks, etc.) on karst hydrogeology; in fact, this special issue is considered a contribution by the IAH Karst Commission. Moreover, there are specific international journals on karst (Acta Carsologica, Carbonates and Evaporites, International Journal of Speleology, Journal of Cave and Karst Studies), and contributions on this subject are published in many scientific journals, as occurs with this Environmental Earth Sciences special issue. In addition, 
various international conferences are periodically organised in which karst hydrogeology is the main topic. Of particular importance are the Conference on Limestone Hydrogeology (Besançon, France and Neuchâtel, Switzerland) and the International Symposium on Karst (Málaga, Spain). Other events are held in Eastern Europe (Croatia, Serbia, Montenegro and Turkey), the USA and Guatemala, among others. Therefore, karst hydrogeology has become consolidated as a scientific branch within the field of hydrogeology.

This special issue describes the progress of research into karst hydrogeology, in part resulting from the 4th International Symposium on Karst (ISKA), held in Málaga (Spain) on 27-30 April 2010. This symposium was organised by the Centre of Hydrogeology at the University of Malaga and the Spanish Geological Survey (IGME), in the framework of their "Advanced Hydrogeological Studies" partnership, with the cooperation of UNESCO, the Nerja Cave Foundation, the Spanish Show Caves Association (ACTE), the Academy of Sciences of Málaga, the Spanish Groundwater Club (CAS) and the IAH Karst Commission who organized its annual meeting during this symposium and awarded the Young Karst Researcher Prize to three young scientists from China, Switzerland and the United Kingdom.

Included in this special issue of the Environmental Earth Sciences journal are expanded versions of selected contributions, which were peer-reviewed by international experts under the supervision of the Editorial Board. Publication of this issue was only possible because of the hard work and enthusiasm of all those mentioned above, and as Guest Editor, I would like to thank them for that. The contributions presented concern methods for groundwater recharge assessment, the time series analysis of spring discharge, the impact of climate change on karst aquifers, natural tracers (chemical, organic carbon, natural fluorescence and isotopes), dye tracers, flash floods, karst groundwater flow, the protection of karst aquifers, pollution and vulnerability in karst and numerical modelling. The advances in karst hydrogeology presented in this issue show that research into groundwater resource assessment, and also into the hydrogeological functioning of aquifers, using different tools, are very necessary for the sustainable management of aquifers, particularly under conditions of climate change. At the same time, advances in protection zoning prove this to be the best preventive tool for land use management. This issue describes relevant techniques for the characterisation and modelling of karst aquifer functioning, which are vital in preventing negative effects such as overexploitation and contamination.

As a compilation of recent investigations, this publication provides a reference of interest for all those investigating the karst medium, and particularly for ongoing projects such as the following: Environmental Change and Sustainability in Karst Systems (IGCP-598 of UNESCO); International Hydrological Programme of UNESCO; and Dinaric Karst Transboundary Aquifer System (DIKTAS project of UNESCO), among many others.

This special issue is an activity of the International Association of Hydrogeologists Karst Commission and it is a contribution to Projects IGCP 598 of UNESCO and CGL2008-06158 of the Spanish Directorate of Research, to Integrated Actions HP2008-047 and DE2009-0060, and to Research Group RNM 308 of the Andalusian Government.

Guest Editor of the Special Issue Bartolomé Andreo 